\title{
Treatment of pulmonary hypertension secondary to connective tissue diseases
}

\author{
Olivier Sanchez, Marc Humbert, Olivier Sitbon, Gérald Simonneau
}

Pulmonary hypertension has been identified as one of the well known life threatening complications of connective tissue diseases. In patients with connective tissue diseases pulmonary hypertension occurs with little or no evidence of parenchymal lung disease. As in primary pulmonary hypertension, the pathophysiology is unknown but the clinical course and pathological findings are similar. Scleroderma, particularly in its CREST variant (calcinosis, Raynaud's phenomenon, oesophageal dysmotility, sclerodactyly, telangiectasias), represents the main connective tissue disease associated with pulmonary hypertension. Prevalence varies from $2.3 \%$ to $35 \%$ in scleroderma $^{1-3}$ and may reach $50 \%$ in the CREST variant. ${ }^{2}$ Pulmonary hypertension occurs in $23-53 \%$ of patients with mixed connective tissue diseases, ${ }^{4-6}$ in $0.5-14 \%$ of cases of systemic lupus erythematosus, ${ }^{7-10}$ and much more rarely in those with rheumatoid arthritis, Sjögren's syndrome, and dermatopolymyositis. Connective tissue diseases represented around $10 \%$ of the 601 cases of pulmonary hypertension referred to our department from 1981 to 1998 . Prognosis is very poor and no curative treatment is available. Stupi et $a l^{1}$ reported a two year survival rate of $40 \%$ in patients with CREST syndrome and pulmonary hypertension compared with $88 \%$ in patients with CREST syndrome without pulmonary hypertension. There are no consensus guidelines for the treatment of pulmonary hypertension secondary to connective tissue diseases. Treatment recommendations, modelled on those of primary pulmonary hypertension, enable us to propose a specific treatment for these patients who were once considered untreatable. Because of the specificity of pulmonary hypertension evaluation and monitoring it is necessary to refer these patients to a centre with expertise in the management of pulmonary vascular diseases. Indeed, the risk of sudden death exists in these patients and the treatment itself can be dangerous, particularly the high doses of calcium channel blockers which may precipitate heart failure because of their negative inotropic properties.

Pneumologie et
Réanimation
Respiratoire, UPRES
"Maladies Vasculaires
Pulmonaires", Hôpital
Antoine Béclère,
Assistance
Publique-Hôpitaux de
Paris, 92140 Clamart,
France
O Sanchez
M Humbert
O Sitbon
G Simonneau
Correspondence to:
Dr M Humbert.

Pneumologie et

Réanimation

"Maladies Vasculaires

Pulmonaires", Hôpital

Beclère,

Publique-Hôpitaux de

Paris, 92140 Clamart

M Humber

Sitbon

Dr M Humbert. guided by symptoms. High altitude should be avoided because of hypoxic vasoconstriction. Warm baths should be taken carefully because the induced cutaneous vasodilation may dramatically decrease cardiac output. Pregnancy is contraindicated because haemodynamic physiological changes may precipitate the patient to fatal right sided heart failure. ${ }^{11}{ }^{12}$ Contraception is therefore always recommended in women of childbearing age (usually mechanical or progestative contraception). Lastly, surgical procedures including open lung biopsies should be avoided as much as possible.

\section{Specific measures}

ANTICOAGULANT THERAPY

The rationale for anticoagulant therapy in the conventional medical treatment for primary pulmonary hypertension is based on the observation, reported in large pathological series, ${ }^{13} 14$ of pulmonary arteriopathy with thrombotic lesions defined by the presence of eccentric intimal fibrosis and recanalised thrombi. Moreover, in patients with primary pulmonary hypertension who die suddenly, fresh intrapulmonary clots may be found at necropsy. One retrospective study ${ }^{15}$ found a significant beneficial effect of anticoagulant therapy on overall survival. In a prospective study Rich et $a l^{16}$ found that survival was significantly improved in patients treated with anticoagulants.

Despite the lack of a randomised prospective long term trial analysing the efficacy of anticoagulation in pulmonary hypertension secondary to connective tissue diseases, anticoagulant therapy is recommended for several reasons. Firstly, pathological findings available in patients with pulmonary hypertension secondary to connective tissue diseases have reported the same microthrombotic lesions. ${ }^{17-20}$ Secondly, these patients are at a high risk for thromboembolic events due to their sedentary life style, venous insufficiency, dilated right sided heart chambers, and low cardiac output which also promotes in situ thrombosis into the pulmonary vascular bed. Thirdly, antiphospholipid antibodies, which are often present in patients with systemic lupus erythematosus, are a well known risk factor for thrombosis. ${ }^{21}$

Warfarin is the most widely used drug in sufficient doses to increase the international normalised ratio (INR) to around 2.0. Some authors recommend an INR of about 3.0 in the presence of antiphospholipid antibodies. ${ }^{22}$ In some cases curative doses of low molecular weight heparin or unfractionated heparin can be used. 
Table 1 Immunosuppressive therapy in patients with pulmonary hypertension secondary to connective tissue diseases (selected literature)

\begin{tabular}{|c|c|c|c|c|c|c|c|c|c|c|c|c|}
\hline $\begin{array}{l}\text { Patient } \\
\text { no. }\end{array}$ & Sex & Age & $C T D$ & $P A P s / d / m$ & $\begin{array}{l}\mathrm{CI} / \\
\mathrm{CO}\end{array}$ & Immunosuppressive therapy & $\begin{array}{l}\text { Vasodilator } \\
\text { therapy }\end{array}$ & Outcome & $\begin{array}{l}\text { Last PAP } \\
s / d / m\end{array}$ & $\begin{array}{l}\text { Last } \\
\text { CI/CO }\end{array}$ & Remarks & References \\
\hline 1 & $\mathrm{~F}$ & 22 & SLE & $94 / 41 / 57$ & $2,2 /-$ & $\begin{array}{l}500 \text { mg pulse } \\
\text { methylprednisolone for } 3 \\
\text { days; prednisone } 0.5 \\
\mathrm{mg} / \mathrm{kg} ; 20 \\
\text { cyclophosphamide } \\
\text { courses }(750 \mathrm{mg}) \text { over a } \\
\text { period of } 32 \text { months }\end{array}$ & $\begin{array}{l}\text { Prazosin } 5 \\
\text { mg/day over } \\
\text { a period of } \\
55 \text { months }\end{array}$ & Improvement & $54 / 18 / 32$ & $3,8 /$ & $\begin{array}{l}\text { Treatment with } \\
\text { vasodilator alone was } \\
\text { ineffective }\end{array}$ & 25 \\
\hline 2 & $\mathrm{~F}$ & 27 & SLE & $78 /-/-$ & ND & $\begin{array}{l}\text { Plasma exchange }+500 \\
\text { mg pulse prednisone for } \\
3 \text { days; } 20 \mathrm{mg} \\
\text { dexamethasone }+20 \mathrm{mg} \\
\text { methotrexate iv every } \\
\text { week for } 4 \text { weeks; } \\
\text { cyclosporin A } 5 \\
\mathrm{mg} / \mathrm{kg} / \text { day }+ \\
\text { fluocortolone } 100 \\
\mathrm{mg} / \text { week for } 4 \text { weeks }\end{array}$ & None & Improvement & $42 /-1-$ & ND & & 26 \\
\hline 3 & $\mathrm{~F}$ & 31 & SLE & $67 /-/-$ & ND & $\begin{array}{l}20 \mathrm{mg} \text { dexamethasone iv } \\
+20 \mathrm{mg} \text { methotrexate iv } \\
\text { once a week }+ \\
\text { cyclosporin A } 5 \\
\mathrm{mg} / \mathrm{kg} / \text { day for } 2 \text { months }\end{array}$ & None & Improvement & $42 /-1-$ & ND & & 26 \\
\hline 4 & $\mathrm{~F}$ & 20 & MCTD & $-1-/ 58$ & ND & $\begin{array}{l}\text { Sequential administration } \\
\text { of methylprednisolone }+ \\
\text { cyclophosphamide }+ \\
\text { cyclosporin A }\end{array}$ & None & Improvement & $-/-/ 41$ & ND & 10 years of follow up & 27 \\
\hline 5 & $\mathrm{~F}$ & 33 & SLE & $88 / 34 / 52$ & $1,8 /-$ & $\begin{array}{l}\text { Cyclophosphamide } \\
\text { infusions } 0.5 \mathrm{mg} / \mathrm{m}^{2} \\
\text { monthly for } 6 \mathrm{months} \\
\text { followed by once } / 3 \\
\text { months in combination } \\
\text { with } 7.5 \mathrm{mg} / \text { day } \\
\text { prednisolone }\end{array}$ & None & Improvement & $66 / 34 / 46$ & $3 /$ & $\begin{array}{l}\text { Negative acute } \\
\text { vasodilator testing; } \\
\text { last PAPs } 67 \mathrm{~mm} \mathrm{Hg} \\
\text { after } 2 \text { years }\end{array}$ & 28 \\
\hline 6 & $\mathrm{~F}$ & 29 & SLE & $115 / 40 / 65$ & 13,84 & $\begin{array}{l}500 \text { mg pulse } \\
\text { methylprednisolone for } 3 \\
\text { days; prednisolone } 80 \\
\text { mg/day }\end{array}$ & $\begin{array}{l}\text { Diltiazem } \\
180 \mathrm{mg} / \text { day }\end{array}$ & Improvement & $65 / 32 / 50$ & $/ 4,6$ & $\begin{array}{l}\text { Last PAPs } 35 \mathrm{~mm} \mathrm{Hg} \\
\text { after } 18 \text { months }\end{array}$ & 29 \\
\hline 7 & $\mathrm{~F}$ & 49 & P Sjo & $100 / 36 / 60$ & ND & $\begin{array}{l}\text { Methylprednisolone } 4 \\
\text { mg/day, azathioprine } 100 \\
\text { mg/day }\end{array}$ & $\begin{array}{l}\text { Nifedipine } \\
\text { and enalapril }\end{array}$ & Improvement & $55 / 18 / 32$ & ND & $\begin{array}{l}\text { Vasodilators were } \\
\text { ineffective alone; two } \\
\text { years of follow up }\end{array}$ & 30 \\
\hline 8 & $\mathrm{~F}$ & 28 & SLE & $74 / 40 / 52$ & $3,4 /-$ & Prednisone $60 \mathrm{mg} /$ day & None & Aggravation & $78 / 40 / 56$ & $2,5 /-$ & $\begin{array}{l}\text { Negative acute } \\
\text { vasodilator testing }\end{array}$ & 8 \\
\hline 9 & $\mathrm{~F}$ & 29 & SLE & $70 / 38 / 47$ & $2,4 /-$ & Prednisone $80 \mathrm{mg} /$ day & None & Stabilisation & $63 / 37 / 43$ & $2,5 /-$ & $\begin{array}{l}\text { Negative acute } \\
\text { vasodilator testing }\end{array}$ & 8 \\
\hline 10 & $\mathrm{~F}$ & 23 & SLE & $70 / 34 / 50$ & ND & Prednisone $60 \mathrm{mg} /$ day & None & Aggravation & ND & ND & & 8 \\
\hline 11 & $\mathrm{~F}$ & 36 & SLE & $58 / 35 / 40$ & $1,1 /-$ & Prednisone $60 \mathrm{mg} /$ day & None & Death & ND & ND & $\begin{array}{l}\text { Negative acute } \\
\text { vasodilator testing }\end{array}$ & 8 \\
\hline
\end{tabular}

$\overline{\mathrm{CTD}}=$ connective tissue disease; SLE = systemic lupus erythematosus; MCTD = mixed connective tissue disease; PSjö = primary Sjögren's syndrome; PAP s/d/m $=$ pulmonary arterial pressure systolic/diastolic $/$ mean $(\mathrm{mm} \mathrm{Hg}) ; \mathrm{CI}=$ cardiac index $\left(1 / \mathrm{min} / \mathrm{m}^{2}\right) ; \mathrm{CO}=$ cardiac output $(1 / \mathrm{min})$.

IMMUNOSUPPRESSIVE THERAPY

The pathogenesis of pulmonary hypertension secondary to connective tissue diseases is unknown but several authors have hypothesised that immunological disturbances promote the development of pulmonary arteriopathy in these patients. Quismorio et $a l^{10}$ have reported the presence of antinuclear antibody and rheumatoid factor in the walls of the pulmonary blood vessels in two patients with pulmonary hypertension secondary to systemic lupus erythematosus. Other studies ${ }^{21}{ }^{23}$ have reported IgG and complement fraction deposits in the vascular endothelium of patients with pulmonary hypertension secondary to connective tissue diseases. Interestingly, such immune deposits are similar to those observed in renal glomeruli. ${ }^{24}$ However, disseminated immune deposits have also been found in the lungs of patients with systemic lupus erythematosus unaffected by pulmonary hypertension. ${ }^{24}$

Some publications have reported a dramatic improvement in patients with pulmonary hypertension secondary to connective tissue diseases following immunosuppressive therapy (table 1). The analysis of the available literature comes up against several difficulties. Firstly, most of the papers are case reports and unpublished negative data are presumably more common. Secondly, it is difficult to evaluate the effects of immunosuppressive therapy alone because of the frequent use of oral vasodilator therapy. Thirdly, immunosuppressive protocols vary from one study to another and comparison is therefore difficult. Lastly, there are no placebo controlled studies of immunosuppressive therapy in patients with pulmonary hypertension secondary to connective tissue diseases. It is therefore difficult to provide guidelines on immunosuppressive therapy in the management of pulmonary hypertension secondary to connective tissue diseases. However, the current literature shows that systemic sclerosis is less responsive to immunosuppressants than systemic lupus erythematosus. Corticosteroids associated with immunosuppressants such as cyclophosphamide in bolus infusion seem to be the most effective treatment to date. Strict clinical and haemodynamic criteria are necessary to evaluate the efficacy of such treatments. In the absence of clear clinical and/or haemodynamic improvement after a few weeks or months the treatment should be 
stopped because of possible life threatening adverse events (mainly infections).

VASODILATOR THERAPY

Pulmonary vasoconstriction is believed to be an important component of the pathogenesis of pulmonary hypertension. ${ }^{31}$ This is based on histopathological studies reporting medial hypertrophy of muscular pulmonary arteries in primary pulmonary hypertension ${ }^{13}{ }^{14}$ as well as in pulmonary hypertension secondary to connective tissue diseases. ${ }^{10}{ }^{17-20} 32$ Raynaud's phenomenon is present in $83 \%$ of patients with pulmonary hypertension secondary to connective tissue diseases ${ }^{33}$ and in 10-14\% of patients with primary pulmonary hypertension. ${ }^{34} 35$ These findings suggest an underlying vasospastic predisposition of pulmonary vessels, the so-called Raynaud's phenomenon of the lung. ${ }^{36}$

The goal of vasodilator therapy is to reduce pulmonary arterial pressure, increase cardiac output, and thus decrease pulmonary vascular resistance without symptomatic systemic hypotension. Unfortunately no clinical, demographic, or haemodynamic variables ${ }^{1637}$ can predict significant vasoreactivity in patients with pulmonary hypertension. Moreover, systematic administration of oral vasodilators in all patients with pulmonary hypertension can induce severe adverse events in non-responders. ${ }^{38}$ For these reasons it is important to test pulmonary vasoreactivity in all patients during initial right heart catheterisation in pulmonary vascular units where there is expertise in this form of testing and treatment with a potent, short acting, and titratable vasodilator such as intravenous epoprostenol (prostacyclin), adenosine, or inhaled nitric oxide (NO). ${ }^{37} \mathrm{NO}$ has the advantage of being the most selective agent for the pulmonary vascular bed; moreover, it induces a comparable individual pulmonary vasodilation to that achieved with epoprostenol. ${ }^{37}$ Responders are usually defined by having a significant fall in both mean pulmonary arterial pressure and total pulmonary resistance of at least $20 \%$ during acute vasodilator testing. ${ }^{16}{ }^{38}$ They should be treated with an oral vasodilator such as calcium channel blockers. In primary pulmonary hypertension a few patients (about 20\%) are responders. ${ }^{1637}$ Few data are available in patients with pulmonary hypertension secondary to connective tissue diseases. Williamson et $a b^{39}$ reported that five out of seven patients with systemic sclerosis and pulmonary hypertension had a decrease in total pulmonary resistance of at least $20 \%$ during acute NO testing, but only one had a decrease in both mean pulmonary arterial pressure and total pulmonary resistance. In our experience 15 out of 57 patients with pulmonary hypertension secondary to connective tissue diseases had a significant fall in total pulmonary resistance, but only four had a combined fall ( $>20 \%)$ in both mean pulmonary arterial pressure and total pulmonary resistance. This proportion seems to be even smaller than that observed in primary pulmonary hypertension. ${ }^{40}$
Oral vasodilators

As indicated above, oral vasodilators should be given to patients who respond acutely to $\mathrm{NO}$ or epoprostenol. Of all the vasodilators tested, calcium channel blockers are the most efficient drugs for long term treatment. Nifedipine and diltiazem are widely used drugs in primary pulmonary hypertension. ${ }^{31}$ Rich et al ${ }^{16}$ reported prolonged survival in patients with primary pulmonary hypertension who were responsive to acute vasodilator testing and were treated with calcium channel blockers compared with those who were unresponsive. Several studies have also reported an acute $e^{11-43}$ and a long term $^{4-46}$ improvement with calcium channel blockers in patients with pulmonary hypertension secondary to connective tissue diseases. Verapamil is not recommended because of its negative inotropic effects. The choice between nifedipine and diltiazem depends on the heart rate at rest; in our institution diltiazem is given to patients with a heart rate of $>80$ beats/min. High doses of calcium channel blockers (nifedipine 90-180 mg/day and diltiazem 360-720 mg/day) are often necessary in this indication. Adverse effects such as systemic hypotension or lower limb oedema may occur. ${ }^{38}$

Angiotensin converting enzyme inhibitors have been also studied in patients with pulmonary hypertension secondary to connective tissue diseases with various results. Niarchos et $a l^{47}$ reported an acute decrease by $26 \%$ of total pulmonary resistance but without any change in mean pulmonary arterial pressure in four out of six patients with pulmonary hypertension secondary to connective tissue diseases. Alpert et $a l^{48}$ showed an acute and sustained reduction in both mean pulmonary arterial pressure and total pulmonary resistance in eight patients with pulmonary hypertension secondary to connective tissue diseases.

\section{Epoprostenol (prostacyclin)}

Epoprostenol (prostaglandin $\mathrm{I}_{2}$, prostacyclin) is a potent vasodilator and inhibitor of platelet aggregation produced by the vascular endothelium. ${ }^{49}$ It reduces pulmonary vascular resistance and increases cardiac output and oxygen delivery when administered acutely to some patients with primary pulmonary hypertension. ${ }^{49}$ Moreover, continuous intravenous epoprostenol produces substantial and sustained haemodynamic and symptomatic responses as well as improving survival in patients with severe primary pulmonary hypertension refractory to conventional medical treatment including oral calcium channel blockers. ${ }^{50}{ }^{51}$ Few data are available in pulmonary hypertension secondary to connective tissue diseases. De La Matta et $a \bar{P}^{2}$ have studied the effects of iloprost, a stable prostacyclin analogue, in three patients with severe pulmonary hypertension secondary to systemic sclerosis who did not respond to oral vasodilators. They showed an improvement in New York Heart Association (NYHA) functional class and exercise tolerance in all patients which contrasted with the modest haemodynamic 
benefit. We have recently reported our experience in 17 patients with connective tissue diseases who developed severe pulmonary hypertension despite immunosuppressive therapy and were unresponsive to oral vasodilator therapy. ${ }^{53}$ All patients received epoprostenol administered by portable infusion pump. During the first six weeks of the study two patients died of pulmonary oedema $(n=1)$ and severe sepsis $(n=1)$. In the 15 remaining subjects the NYHA functional class, exercise capacity, and all haemodynamic parameters improved significantly. These patients were then monitored for a mean (SD) of 80 (48) weeks (range 14-154) after initiation of epoprostenol. Five patients died of right heart failure $(n=2)$, syncope $(n=1)$, or severe sepsis ( $=2$ ) and two patients were successfully transplanted. Seven of the remaining eight patients had persistent clinical and haemodynamic improvement. These results indicate that short term continuous intravenous epoprostenol together with conventional therapy is effective in most patients with severe pulmonary hypertension secondary to connective tissue diseases who fail to respond to oral calcium channel blockers. However, further studies are needed to evaluate the efficacy of long term epoprostenol therapy in pulmonary hypertension secondary to connective tissue diseases.

Other intravenous vasodilators

Ketanserin, a selective antagonist of $\mathrm{S}_{2}-$ serotonergic receptors, has been tested acutely in patients with pulmonary hypertension secondary to systemic sclerosis with a modest vasodilator effect in a few patients. ${ }^{54}$

\section{Transplantation}

Heart-lung, single, and double lung transplantation have been performed successfully in patients with primary pulmonary hypertension. ${ }^{55-57}$ Patients with connective tissue diseases have been often excluded from transplantation because of previous immunosuppressive therapy and possible involvement of other organs such as the kidneys or liver with the underlying disease. Nonetheless, Levy et al reported prolonged survival after heart-lung transplantation in patients with pulmonary hypertension secondary to connective tissue diseases. ${ }^{50}$ In our centre three patients, two with a CREST syndrome and one with systemic lupus erythematosus, have been successfully transplanted.

\section{Minor measures}

OXYGEN THERAPY

Moderate hypoxia is a common finding at rest in pulmonary hypertension secondary to connective tissue diseases. It is the consequence of one or more of the following mechanisms: (1) impaired cardiac output resulting in low mixed venous pulmonary saturation $\left(\mathrm{SvO}_{2}\right),(2)$ rightto-left shunting through a patent foramen ovale, (3) alveolar hypoxia in cases of parenchymal lung disease which may in turn worsen pulmonary hypertension by hypoxic vasoconstriction. One study reported a beneficial haemodynamic effect of an acute administration of oxygen in patients with pulmonary hypertension associated with systemic sclerosis. ${ }^{58}$

DIURETICS

Diuretics are used to reduce intravascular volume and hepatic congestion which occur in patients with right sided heart failure. However, hypovolaemia induced by excessive diuresis can provoke a fall in cardiac output due to a decreased right ventricle preload and careful monitoring is required to prevent it. Furosemide and/or spironolactone may be prescribed and the dose increased as needed.

\section{DIGITALIS COMPOUNDS}

Some authors prescribe digitalis compounds in association with diuretics. These agents are less efficient than specific therapies such as vasodilators. Furthermore, toxicity to digitalis may be enhanced if hypoxaemia and diuretic induced hypokalaemia are also present.

\section{Conclusion}

In the absence of major trials in pulmonary hypertension secondary to connective tissue diseases, treatment should be conducted in the same way as for primary pulmonary hypertension. The only difference is that immunosuppressive therapy may be effective in a few patients with pulmonary hypertension secondary to connective tissue diseases (mainly pulmonary hypertension related to systemic lupus erythematosus). Conventional therapy includes general measures, supplemental oxygen, diuretics, anticoagulants and, in some institutions, digitalis compounds. Oral vasodilators such as calcium channel blockers should only be given to patients with an acute vasodilator response revealed during right heart catheterisation. The use of continuous epoprostenol treatment is currently being evaluated in this indication. The results of a large multicentre study in the USA will be published shortly and should confirm our preliminary results. However, the efficacy of long term epoprostenol infusion on survival has to be evaluated in this patient population. ${ }^{59} 60$ Lastly, lung and heart-lung transplantation can be indicated in some patients with severe pulmonary hypertension secondary to connective tissue diseases.

This study has been supported in part by Université Paris-Sud.

1 Stupi AM, Steen VD, Owens GR, et al. Pulmonary hypertension in the CREST syndrome variant of systemic sclerosis. Arthritis Rheum 1986;29:515-24.

2 Ungerer RG, Tashkin DP, Furst D, et al. Prevalence and clinical correlates of pulmonary arterial hypertension in progressive systemic sclerosis. Am f Med 1983;75:65-74.

3 Salerni R, Rodnan GP, Leon DF, et al. Pulmonary hypertension in the CREST syndrome variant of progressive systemic sclerosis (scleroderma). Ann Intern Med 1977;86:394-9.

4 Alpert MA, Goldberg SH, Singsen $\mathrm{BH}$, et al. Cardiovascular manifestations of mixed connective tissue disease in adults. Circulation 1983;68:1182-93.

5 Hosoda Y, Suzuki Y, Takano M, et al. Mixed connective tissue disease with pulmonary hypertension: a clinical and pathological study. $\mathcal{F}$ Rheumatol 1987;14:826-30.

6 Sullivan WD, Hurst DJ, Harmon CE, et al. A prospective evaluation emphasizing pulmonary involvement in patients with mixed connective tissue disease. Medicine 1984;63:92with 
7 Asherson RA, Higenbottam TW, Dinh Xuan AT, et al. Pulmonary hypertension in a lupus clinic: experience with
twenty four patients. $\mathcal{F}$ Rheumatol $1990 ; 17: 1292-8$.

8 Perez HD, Kramer N. Pulmonary hypertension in systemic lupus erythematosus: report of four cases and review of the literature. Semin Arthritis Rheum 1981;11:177-81.

9 Simonson JS, Schiller NB, Petri M, et al. Pulmonary hypertension in systemic lupus erythematosus. I Rheumato 1989;16:918-25

10 Quismorio FP, Sharma O, Koss M, et al. Immunopathologic and clinical studies in pulmonary hypertension associated with systemic lupus erythematosus. Semin Arthriti Rheum 1984;13:349-59.

11 Ray J, Sermer M. Systemic lupus erythematosus and pulmonary hypertension during pregnancy: report of a case fatality. Can ₹ Cardiol 1996;12:753-6.

12 Rubin LA, Geran A, Rose TH, et al. A fatal pulmonary complication of lupus in pregnancy. Arthritis Rheum 1995; 38:710-4.

13 Palevsky HI, Schloo BL, Pietra GG, et al. Primary pulmonary hypertension: vascular structure, morphometry, and responsiveness to vasodilator agents. Circulation etry, and responsiven

14 Bjornsson J, Edwards WD. Primary pulmonary hypertension: a histopathologic study of 80 cases. Mayo Clin Proc 1985;60:16-25.

15 Fuster V, Steele PM, Edwards WD, et al. Primary pulmonary hypertension: natural history and the importance of thrombosis. Circulation 1984;70:580-7.

16 Rich S, Kaufman E, Levy PS. The effect of high doses of calcium-channel blockers on survival in primary pulmonary hypertension. $N$ Engl f Med 1992;327:76-81.

17 Naeye RL. Pulmonary vascular lesions in systemic scleroderma. Dis Chest 1963;44:374-80.

18 Bunch TW, Tancredi RG, Lie JT. Pulmonary hypertension in polymyositis. Chest 1981;79:105-7.

19 Balagopal VP, Da Costa P, Greenstone MA. Fatal pulmonary hypertension and rheumatoid vasculitis. Eur pulmonary hypertensio
Respir $\mathcal{F}$ 1995;8:331-3.

20 Sato T, Matsubara O, Tanaka Y, et al. Association of Sjögren syndrome with pulmonary hypertension: report of two cases and review of the literature. Hum Pathol 1993:24: 199-205.

21 Asherson RA, Cervera R. Review: antiphospholipid antibodies and the lung. F Rheumatol 1995;22:62-6.

22 Khamashta MA, Cuadraro MJ, Mujic F, et al. The management of thrombosis in the antiphospholipid antibody syndrome. N Engl f Med 1995;332:993-7.

23 Yeo PPB, Sinniah R. Lupus cor pulmonale with electron micoscope and immunofluorescent antibody studies. Ann Rheum Dis 1975;34:457-8.

24 Brentjens J, Ossi E, Albini B, et al. Disseminated immune deposits in lupus erythematosus. Arthritis Rheum 1977;20: 962-8.

25 Karmochkine M, Wechsler B, Godeau P, et al. Improvement of severe pulmonary hypertension in a patient with systemic lupus erythematosus. Ann Rheum Dis 1996;55: 561-2.

26 Morelli S, Giordano M, De Marzio P, et al. Pulmonary arterial hypertension responsive to immunosuppressive therapy in systemic lupus erythematosus. Lupus 1993;2:367-9.

27 Dahl M, Chalmers A, Wade J, et al. Ten years survival of a patient with advanced pulmonary hypertension and mixed connective tissue disease treated with immunosuppressive therapy. F Rheumatol 1992;19:1807-9.

28 Groen H, Bootsma H, Postma DS, et al. Primary pulmonary hypertension in a patient with systemic lupus erythematosus: partial improvement with cyclophosphamide. F Rheumatol 1993;20:1055-7.

29 Goupille P, Fauchier L, Babuty D, et al. Precapillary pulmonary hypertension dramatically improved with high doses of corticosteroids during systemic lupus erythematosus. $f$ Rheumatol 1994;21:1976-7.

30 Gallerani M, Govoni M, Ricci L, et al. A 49-year-old woman with dyspnea, palpitations and syncope. Int f Cardiol 1996; 55:67-78.

31 Rubin LJ. Primary pulmonary hypertension. N Engl f Med 1997;336:111-7.

32 Hosoda Y, Suzuki Y, Takano M, et al. Mixed connective tissue disease with pulmonary hypertension: a clinical and pathological study. $\mathcal{F}$ Rheumatol $1987 ; 14: 826-30$.

33 Brundage $\mathrm{BH}$. Pulmonary hypertension in collagen vascular disease. In: Fishman A, ed. The pulmonary circulation. Philadelphia: University of Pennsylvania Press, 1990: 353-8.

34 Rich S, Dantzker DR, Ayres SM, et al. Primary pulmonary hypertension. A national prospective study. Ann Intern Med 1987; 107:216-23.

35 Brenot F. Primary pulmonary hypertension. Case series from France. Chest 1994;105:33-6S.
36 Fahey PJ, Utell MJ, Condemi JJ, et al. Raynaud's phenomenon of the lung. Am F Med 1984;76:263-9.

37 Sitbon O, Brenot F, Denjean A, et al. Inhaled nitric oxide as a screening vasodilator agent in primary pulmonary hypertension. Am f Respir Crit Care Med 1995;151:384-9.

38 Sitbon O, Humbert M, Jagot JL, et al. Inhaled nitric oxide as a screening agent to safely identify responders to oral calcium-channel blockers in primary pulmonary hypertension. Eur Respir F 1998;12:265-70.

39 Williamson DJ, Hayward C, Rogers P, et al. Acute hemodynamic responses to inhaled nitric oxide in patients with limited scleroderma and isolated pulmonary hypertension. Circulation 1996;94:477-82.

40 Sanchez O, Sitbon O, Humbert M, et al. Acute hemodynamic responses to vasodilators in patients with connective tissue diseases and pulmonary hypertension. Eur Respir $\mathcal{F}$ $1998 \cdot 12: 428 \mathrm{~S}$

41 Jolliet P, Thorens JB, Chevrolet JC. Pulmonary vascular reactivity in severe pulmonary hypertension associated with mixed connective tissue disease. Thorax 1995;50:96-7.

42 Ocken S, Reinitz E, Strom J. Nifedipine treatment for pulmonary hypertension in a patient with systemic sclerosis. Arthritis Rheum 1983;26:794-6.

43 Glickson M, Pollack A, Dresner-Feigin R, et al. Nifedipine and prazosin in the management of pulmonary hyperand prazosin in the management of pulmonary hyp

44 Shinohara S, Murata I, Yamada H, et al. Combined effects of diltiazem and oxygen in pulmonary hypertension of mixed connective tissue disease. $\mathcal{F}$ Rheumatol 1994;21: 1763-5.

45 O'Brien JT, Hill JA, Pepine CJ. Sustained benefit of verapamil in pulmonary hypertension with progressive systemic sclerosis. Am Heart f 1985;109:380-2.

46 Alpert MA, Pressly TA, Mukerji V, et al. Acute and long term effects of nifedipine on pulmonary and systemic hemodynamics in patients with pulmonary hypertension associated with diffuse systemic sclerosis, the CREST syndrome and mixed connective tissue disease. Am 7 Cardiol 1991;68:1687-91

47 Niarchos AP, Whitman $\mathrm{HH}$, Goldstein JE, et al. Hemodynamic effects of captopril in pulmonary hyperte collagen vascular disease. Am Heart f 1982;104:834-8.

48 Alpert MA, Pressly TA, Mukerji V, et al. Short and long-term hemodynamic effects of captopril in patients with pulmonary hypertension and selected connective with pulmonary hypertension and se

49 Rubin LJ, Groves BM, Reeves JT, et al. Prostacyclin induced acute pulmonary vasodilation in primary pulmonary hypertension. Circulation 1982;66:334-8.

50 Barst RJ, Rubin LJ, Long WA, et al. A comparison of continuous intravenous epoprostenol (prostacyclin) with conventional therapy for primary pulmonary hypertension. N Engl f Med 1996;334:296-301.

51 McLaughlinVV, Genthner DE, Panella MM, et al. Reduction in pulmonary vascular resistance with long-term epoprostenol (prostacyclin) therapy in primary pulmonary hypertension. N Engl F Med 1998;338:273-7.

52 De La Mata J, Gomez-Sanchez MA, Aranzana M, et al. Long-term iloprost infusion therapy for severe pulmonary hypertension in patients with connective tissue diseases. Arthritis Rheum 1994;37:1528-33.

53 Humbert M, Sanchez O, Fartoukh M, et al. Treatment of severe pulmonary hypertension secondary to connective tissue diseases with continuous intravenous epoprostenol (prostacyclin). Chest 1998;114:80-2S.

54 Seibold JR, Molony RR, Turkevich D, et al. Acute hemodynamic effects of ketanserin in pulmorary hypertension secondary to systemic sclerosis. $\mathcal{F}$ Rheumatol $1987 ; 14: 519-24$

5 Levine SM, Gibbons WJ, Bryan CL, et al. Single lung transplantation for primary pulmonary hypertension. Chest 1990;98:1107-15.

56 Reitz BA, Wallwork JL, Hunt SA, et al. Heart-lung transplantation: successful therapy for patients with pulmonary vascular disease. $N$ Engl f Med 1982;306:557-64.

57 Levy RD, Guerraty AJ, Yacoub $\mathrm{MH}$, et al. Prolonged survival after heart-lung transplantation in systemic lupus erythematosus. Chest 1993;104:1903-5.

58 Morgan JM, Griffiths M, du Bois RM, et al. Hypoxic pulmonary vasoconstriction in systemic sclerosis and pulmonary vasoconstriction in systemic sclerosis and
primary pulmonary hypertension. Chest 1991;99:551-6.

59 Humbert M, Sanchez O, Fartoukh M, et al. Short-term and long-term epoprostenol (prostacyclin) therapy in pulmonary hypertension secondary to connective tissue diseases: result of a pilot study. Eur Respir 71999 (in press).

60 Sitbon O, Humbert M, Sanchez O, et al. Survival in pulmonary hypertension associated with connective tissue diseases (PH-CTD) treated with long-term epoprostenol $\left(\mathrm{PgI}_{2}\right)$ : comparison with primary pulmonary hypertension (PPH). Am F Respir Crit Care Med 1999; in press (abstract). 